\title{
CULTURA IN VITRO DE EMBRIÕES ZIGÓTICOS DE AÇAIZEIRO ${ }^{1}$
}

\author{
ANA DA SILVA LEDO ${ }^{2}$, OSMAR ALVES LAMEIRA ${ }^{3}$, ABDELLATIF K. BENBADIS ${ }^{4}$, \\ ILMARINA CAMPOS DE MENEZES ${ }^{5}$, CARLOS ALBERTO DA SILVA LEDO ${ }^{6}$, \\ MARIA DO SOCORRO PADILHA DE OLIVEIRA ${ }^{7}$
}

\begin{abstract}
RESUMO- Este trabalho teve como objetivo estabelecer o protocolo para a produção de plântulas in vitro a partir da conversão de embriões zigóticos de açaizeiro (Euterpe oleracea Mart.). Os embriões zigóticos maduros foram excisados sob condições assépticas, a partir de sementes obtidas de frutos maduros, e cultivados em tubos de ensaio com $10 \mathrm{~mL}$ de meio MS modificado pela presença de 0,17 g.L $\mathrm{L}^{-1}$ de $\mathrm{NaH}_{2} \mathrm{PO}_{4}$, com $0,6 \%$ de ágar, $0,25 \%$ de carvão ativado e $3 \%$ de sacarose. Foram testadas diferentes combinações de ANA $(0,54 ; 2,68$ e $5,37 \mu \mathrm{M})$ e BAP $(0,44 ; 1,11 ; 1,55$ e $2,22 \mu \mathrm{M})$ e uma testemunha adicional. Em média, os tratamentos constituídos da combinação de ANA e BAP foram superiores à testemunha para todas as variáveis avaliadas. As concentrações de 0,54 e $2,68 \mu \mathrm{M}$ de ANA promoveram, em média, maior formação de plântulas normais quando comparado com 5,37 $\mu \mathrm{M}$ de ANA. O maior comprimento da parte aérea foi induzido pela presença de $2,68 \mu \mathrm{M}$ de ANA combinado com 1,11;1,55 e 2,22 $\mu \mathrm{M}$ de BAP. Não foram verificadas diferenças significativas entre as concentrações de ANA e BAP para a percentagem de conversão de embriões e número de raízes por plântula.
\end{abstract}

Termos para indexação: conversão in vitro, Euterpe oleracea, meios de cultura, regulador de crescimento

\section{IN VITRO CULTURE OF ASSAI PALM ZYGOTIC EMBRYOS}

\begin{abstract}
This work had as objective to establish protocol for the production of seedlings in vitro from of the conversion of assai palm zygotic embryos (Euterpe oleracea Mart.). The mature zygotic embryos obtained of seeds of mature fruits were excised under aseptic conditions, and cultivated in rehearsal tubes with $10 \mathrm{~mL}$ of a MS medium modified by the presence of 0,17 g.L. $\mathrm{L}^{-1} \mathrm{NaH}_{2} \mathrm{PO}_{4}$, with agar $0,6 \%, 0,25 \%$ activated charcoal and $3 \%$ sucrose. Different combinations of NAA were tested $(0,54 ; 2,68$ and $5,37 \mu \mathrm{M})$ and $\operatorname{BAP}(0,44 ; 1,11 ; 1,55$ and $2,22 \mu \mathrm{M})$ and a treatment without growth regulator. On the average, the constituted treatments of ANA and BAP were superiors the to a treatment without growth regulator to all the parameters. The concentrations of 0,54 and $2,68 \mu \mathrm{M}$ of NAA promoted, on the average, larger formation of normal seedlings when compared with 5,37 $\mu \mathrm{M}$ NAA. The presence of $2,68 \mu \mathrm{M}$ NAA plus 1,11; 1,55 and 2,22 $\mu \mathrm{M}$ BAP was induced largest shoot length. Significant differences were not verified between NAA and BAP concentrations for the number of roots/seedlings. The obtained results allowed verifying that an addition of NAA and BAP in the culture medium was necessary to the conversion of mature zygotic embryos in both vigorous and normal seedlings.
\end{abstract}

Index terms: in vitro conversion, Euterpe oleracea, culture media, growth regulator

\section{INTRODUÇÃO}

O açaizeiro (Euterpe oleracea Mart.) é uma palmeira tipicamente tropical e está distribuída geograficamente na América do Sul, principalmente no Brasil, nos Estados do Pará, Amazonas, Acre, Amapá e Maranhão (Kahn, 1997). É uma planta dominante em áreas de mata do estuário amazônico, fazendo parte da vegetação de terra firme, várzea e igapó, sendo mais comum em áreas de várzeas, onde chega a formar populações homogêneas (Jardim et al., 1995).

Dentre as diversas espécies nativas da região Amazônica, o açaizeiro destaca-se com grande potencial de exploração socioeconômico, visto que pode ser utilizado integralmente para a exploração econômica de frutos, palmito e celulose. De seus frutos, obtém-se um suco denominado de açaí, que tem grande aceitação no mercado regional e, atualmente, devido ao seu excelente valor nutritivo e calórico, vem conquistando os mercados nacional e internacional, sendo comercializado "in natura", como suco gelado, na fabricação de geléias, sorvetes e picolés (O Sabor..., 1992).

A propagação in vitro constitui-se numa ferramenta de grande importância para plantas com dificuldade de serem multiplicadas vegetativamente (Robles, 1983), como é o caso das palmeiras e, mais especificamente, do açaizeiro, onde o pegamento de perfilhos é menor que $1 \%$. Esta técnica tem despertado interesse por facilitar a produção de mudas de material

1 (Trabalho 271/2000). Recebido: 19/12/2000. Aceito para publicação: 04/10/2001. Parte da tese de Doutorado do primeiro autor, financiada com recursos da Embrapa Amazônia Oriental/JICA.

2 Eng ${ }^{\text {Agr }}{ }^{\text {a }}$ D.Sc., pesquisadora da Embrapa-Acre, caixa postal 392, CEP. 69900-000, Rio Branco-AC, e-mail: analedo@cpafac.embrapa.br.

3 Eng $^{\circ}$ Agr $^{\circ}$ D.Sc., pesquisador da Embrapa Amazônia Oriental, caixa postal 48, CEP 66017-970, Belém-PA.

4 Eng $^{\circ}$ Agr $^{\circ}$ PhD., professor visitante do Departamento de Fitotecnia da UFC, Av. Mister Hull, s/n, CEP. 60020-181, Campus do Pici, FortalezaCE.

5 Eng $^{\text {a }}$ Agr $^{\mathrm{a}}$ M.Sc., Técnica de Nível Superior da Embrapa Amazônia Oriental.

6 Eng $^{\circ}$ Agr $^{\circ}$ M.Sc., doutorando da Universidade Federal de Lavras, Caixa Postal 37, CEP 37200-000, Lavras-MG.

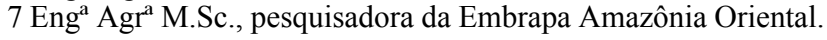


elite em escala comercial, por produzir plantas livres de patógenos e acelerar programas de melhoramento que, no caso de palmeiras, são demorados e complexos em virtude do longo ciclo, hábito de crescimento e ausência de métodos convencionais de propagação vegetativa em virtude da ausência de câmbio vascular em monocotiledôneas.

Dentre as técnicas de cultura de tecidos, a cultura de embriões, por tentar reproduzir in vitro o normal desenvolvimento de embriões, apresenta-se como uma ferramenta para o controle da embriogênese, o resgate de embriões interespecíficos, quando apresentam alguma incompatibilidade, a produção de haplóides, a quebra de dormência e a produção de plântulas assépticas, além de elucidar alguns problemas como nutrição do embrião no óvulo entre outras aplicações (Collins \& Grosser, 1984; Hu \& Ferreira, 1998).

Conforme relatado por $\mathrm{Hu} \&$ Ferreira (1998), embriões excisados no estádio maduro ou próximo a este são quase autotróficos e, em geral, dependendo da espécie, não há necessidade de suplementação de fonte de energia, podendo germinar e crescer num meio inorgânico, e os reguladores de crescimento tornam-se dispensáveis.

Os objetivos do presente trabalho foram avaliar o efeito da adição de ANA e BAP no meio de cultura e estabelecer um protocolo para a conversão in vitro de embriões zigóticos de açaizeiro.

\section{MATERIAL E MÉTODOS}

O estudo foi conduzido no Laboratório de Recursos Genéticos e Biotecnologia da Embrapa Amazônia Oriental, em Belém-Pará. Frutos maduros, obtidos da coleção de germoplasma de açaizeiro da Embrapa Amazônia Oriental e com peso médio de 2,35 g, foram lavados em água corrente e submetidos ao despolpamento em água a $40^{\circ} \mathrm{C}$. As sementes foram desinfestadas em câmara de fluxo laminar, com a imersão em álcool etílico a 70 \% por dois minutos e, em seguida, em solução de $\mathrm{NaClO}$ a $2 \%$ por 20 minutos sob agitação e, posteriormente, foram lavadas quatro vezes em água destilada e autoclavada.

Os embriões zigóticos, excisados de sementes assépticas sob câmara de fluxo laminar, foram inicialmente inoculados, em tubos de ensaio contendo $10 \mathrm{~mL}$ de meio de cultura MS (Murashige \& Skoog, 1962), modificado pela ausência de vitaminas e aminoácidos, suplementado com $0,6 \%$ de ágar e 0,25 $\%$ de carvão ativado. $\mathrm{O} \mathrm{pH}$ do meio de cultura foi ajustado para 5,8 e, em seguida, submetido à esterilização autoclave a $120^{\circ} \mathrm{C}$ durante 15 minutos.

As culturas foram mantidas em sala de crescimento com temperatura de $26^{\circ} \pm 2^{\circ} \mathrm{C}$, umidade relativa do ar média em torno de $70 \%$ e fotoperíodo de 16 horas de luz branca fria sob 52 umol. $\mathrm{m}^{-2} \cdot \mathrm{s}^{-1}$ de irradiância/ oito horas de escuro.

Aos três dias da inoculação, foi realizada a avaliação quanto às percentagens de contaminação por microorganismos e de oxidação. Em seguida, os embriões foram transferidos para tubos de ensaio com $10 \mathrm{~mL}$ de meio MS modificado pela presença de 0,17 g.L. ${ }^{-1}$ de $\mathrm{NaH}_{2} \mathrm{PO}_{4}$, com 0,6 \% de ágar, $0,25 \%$ de carvão ativado e $3 \%$ de sacarose, suplementado com diferentes combinações de ácido naftalenoacético (ANA) e 6benzilaminopurina (BAP), ajustando-se o $\mathrm{pH}$ a 5,8 antes da autoclavagem.

Foram testadas três concentrações de ANA $(0,54 ; 2,68$ e $5,37 \mu \mathrm{M})$ combinadas com quatro de $\operatorname{BAP}(0,44 ; 1,11 ; 1,55$ e 2,22 $\mu \mathrm{M})$ e uma testemunha adicional (sem regulador de crescimento), perfazendo um total de 13 tratamentos.

O delineamento estatístico utilizado foi o inteiramente casualizado, com quatro repetições. Cada unidade experimental foi constituída de 10 tubos de ensaio, contendo um explante cada.

Aos 10 dias após a inoculação, avaliou-se a percentagem de conversão de embriões zigóticos em plântulas e, aos 48 dias, a percentagem de plântulas anormais, o comprimento da parte aérea $(\mathrm{mm})$ e o número de raízes por plântula. Como plântulas anormais, foram consideradas aquelas que apresentavam ausência ou crescimento atrofiado da parte aérea, do sistema radicular atrofiado e do haustório. As variáveis foram submetidas à análise de variância pelo teste $\mathrm{F}$ e as médias comparadas pelo agrupamento de Skott \& Knott, em nível de 5\% de probabilidade.

\section{RESULTADOS E DISCUSSÃO}

$\mathrm{Na}$ primeira semana de cultura, observaram-se o intumescimento dos embriões zigóticos e o início da expansão da lâmina cotiledonar na região basal, estrutura correspondente ao haustório que, devido a sua atividade digestiva, substitui progressivamente o albúmen no processo de germinação. Os tecidos do nó cotiledonar apresentavam-se intumescidos e avermelhados. Aos 14 dias, foi observada a emissão da radícula e do coleóptilo cotiledonar a partir da região apical periférica. $\mathrm{Na}$ terceira semana, verificaram-se a formação do pecíolo a partir do coleóptilo, o início da expansão do limbo foliar e a emissão de raízes secundárias (Figura 1A). Nas plântulas normais, observouse o rápido crescimento do haustório que, aos 60 dias, se apresentava com coloração branca e consistência esponjosa, sendo que, nas plântulas anormais se apresentava atrofiado (Figura 1B).

A análise de variância detectou efeitos significativos da interação "ANA x BAP" para o comprimento da parte aérea (P $=0,01)$ e do ANA para a percentagem de plântulas normais ( $\mathrm{P}$ $=0,05)($ Tabela 1$)$.

O contraste "Fatorial vs Testemunha" $(\mathrm{y}=\mathrm{xF}-\mathrm{xTe})$ foi significativo, sendo que os valores da estimativa do contraste para todas as variáveis avaliadas foram positivos (Tabela 1), ou seja, em média, os tratamentos constituídos da combinação de ANA e BAP foram superiores à testemunha.

Observa-se, na Figura 2A, que as maiores percentagens de conversão de embriões zigóticos e formação de plântulas normais foram verificadas, em média, em todos os tratamentos constituídos da presença de ANA e BAP quando comparado com a testemunha. Estes resultados concordam com Lemos et al. (1999), que observaram apenas $25 \%$ de conversão de embriões de Euterpe oleracea Mart., com a formação de apenas 12,5 \% de plântulas normais na ausência de ANA e BAP. Llano-Agudelo et al.(1995) obtiveram $85,7 \%$ e 83,3 \% de conversão de embriões zigóticos maduros de Persea americana Mill cv. Americana em meio MS suplementado com 0,3 mg.L $\mathrm{L}^{-1}$ de AIB e 1,0 mg.L $\mathrm{L}^{-1}$ de KIN e 0,1 mg.L $\mathrm{L}^{-1}$ de AIB e 0,3 mg.L ${ }^{-1}$ de KIN, respectivamente. Entretanto, Yokoo et al. (1992) obtiveram a formação de plântulas 

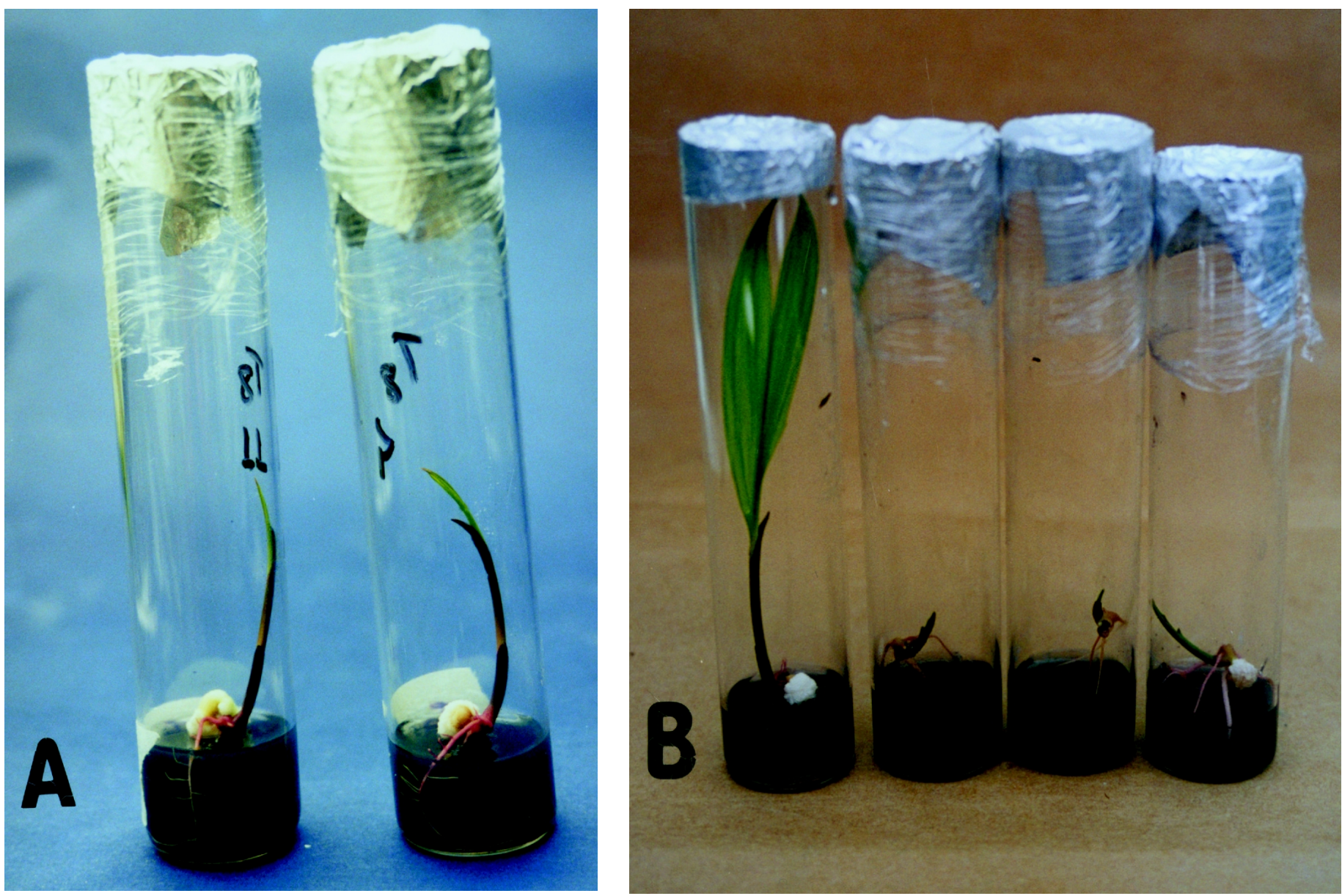

FIGURA 1 - Conversão de embriões zigóticos de Euterpe oleracea Mart. A- início da expansão do limbo foliar e de raízes secundárias; B- plântulas normais e anormais aos 60 dias de cultura. Embrapa Amazônia Oriental, Belém-PA, 2000.

TABELA 1- Resumo da análise de variância para médias da percentagem de conversão de embriões zigóticos (\%CEZ), da percentagem de plântulas normais (\%PN), do comprimento da parte aérea (CPA) e do número de raízes (NR) de plântulas de Euterpe oleracea Mart., em meio MS suplementado com diferentes concentrações de ANA e de BAP. Embrapa Amazônia Oriental, Belém-PA, Brasil, 2000.

\begin{tabular}{lccccc}
\hline Fontes de Variação & G.L. & \multicolumn{4}{c}{ Quadrados Médios } \\
\cline { 3 - 5 } & & $\%$ CEZ & $\%$ PN & CPA(mm) & NR \\
\hline ANA & 2 & $118,75 \mathrm{~ns}$ & $3249,87^{* *}$ & $48,47 \mathrm{~ns}$ & $0,1600 \mathrm{~ns}$ \\
BAP & 3 & $190,97 \mathrm{~ns}$ & $395,32 \mathrm{~ns}$ & $48,78 \mathrm{~ns}$ & $0,1929 \mathrm{~ns}$ \\
ANA x BAP & 6 & $257,64 \mathrm{~ns}$ & $362,22 \mathrm{~ns}$ & $106,15^{*}$ & $0,0896 \mathrm{~ns}$ \\
Fatorial vs Testemunha & 1 & $5020,67^{* *}$ & $2734,64^{*}$ & $243,75^{*}$ & $2,1140^{*}$ \\
Resíduo & 39 & 150,64 & 272,24 & 27,18 & 0,2069 \\
\hline Estimativa do contraste & & 442,50 & 326,57 & 97,50 & 9,08 \\
\hline CV (\%) & & 13,78 & 23,38 & 17,87 & 18,26 \\
\hline
\end{tabular}

* - significativo em nível de $5 \%$ pelo teste $\mathrm{F} ;{ }^{* *}$ - significativo ao nível de $1 \%$ pelo teste $\mathrm{F}$; ns - não significativo 


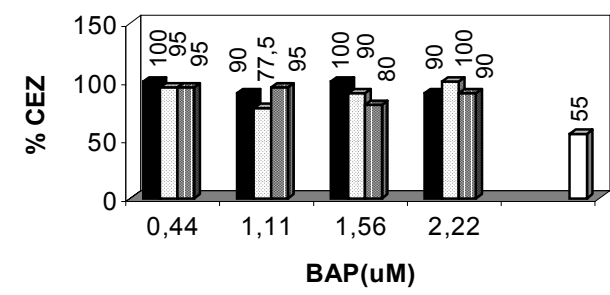

(A)

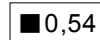

$\square 2,68$

$\square 5,37$

$\square$ test.

ANA $(u M)$

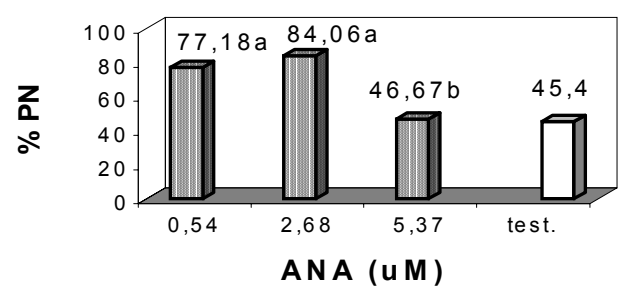

(B)

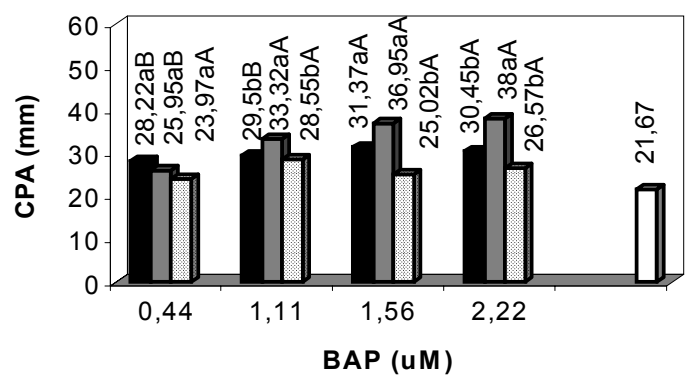

(C)

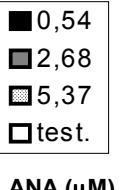

ANA ( $\mu \mathrm{M})$

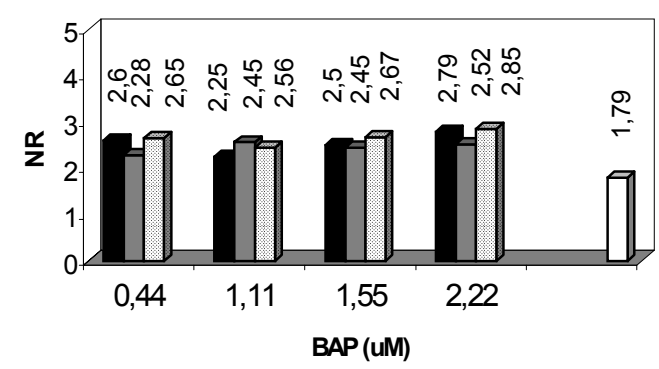

(D)

\begin{tabular}{|c|}
\hline$\square 0,54$ \\
$\square 2,68$ \\
$\square 5,37$ \\
$\square$ test. \\
\hline ANA ( $\mu \mathrm{M})$
\end{tabular}

FIGURA 2- (A)- percentagem de conversão de embriões; (B)percentagem de plântulas normais, (C)comprimento médio da parte aérea $(\mathrm{mm}),(\mathrm{D})$ número médio de raízes/plântula, em resposta à presença e ausência de ANA e BAP no meio de cultura MS na conversão in vitro de embriões zigóticos maduros de Euterpe oleracea Mart. Embrapa Amazônia Oriental, Belém-PA, 2000.

completas, a partir de embriões zigóticos de Euterpe oleracea Mart. e do híbrido Euterpe oleracea $\mathrm{x}$ Euterpe edulis, em meio MS modificado na ausência de reguladores de crescimento.

Conforme Hu \& Ferreira (1998), embriões excisados no estádio maduro ou próximo a este são quase autotróficos e, em geral, dependendo da espécie, não há necessidade de suplementação de fonte de energia, e os reguladores de crescimento tornam-se dispensáveis. Entretanto, no presente trabalho, ficou evidenciada a necessidade de enriquecimento do meio com reguladores de crescimento considerando que, na ausência destes, obteve-se $55 \%$ de conversão de embriões e a formação de 45,42 \% de plântulas anormais (Figuras 2A e 2B). Provavelmente, além da espécie e do estádio de desenvolvimento dos embriões, o nível endógeno de fitormônios nos explantes deve ser considerado na cultura de embriões.

As concentrações de 0,54 e 2,68 $\mu \mathrm{M}$ de ANA promoveram, em média, maior formação de plântulas normais quando comparado com o nível de 5,37 $\mu \mathrm{M}$ de ANA (Figura 2B). Elevadas concentrações de auxinas induzem, predominantemente, a formação de raízes em detrimento da formação da parte aérea, conforme relatado por Skoog \& Miller (1957), podendo este fato ter contribuído para a maior conversão de embriões em plântulas anormais em elevada concentração de ANA.

O maior crescimento da parte aérea foi induzido pela presença de 2,68 $\mu \mathrm{M}$ de ANA, combinado com 1,11; 1,55 e 2,22 $\mu \mathrm{M}$ de BAP (Figura 2C). Em concentração elevada de ANA (5,37 $\mu \mathrm{M}$ ), foi observado o menor desenvolvimento da parte aérea das plântulas em todas as combinações de BAP. Não foram verificadas diferenças significativas $(P>0,05)$ entre as concentrações de ANA e BAP para o número de raízes por plântula; entretanto, estes tratamentos apresentaram desempenho superior quando comparados à testemunha (Figura 2D).

\section{CONCLUSÕES}

Com base nos resultados obtidos e nas condições em que o trabalho foi conduzido, pode-se concluir:

1 - É possível a conversão in vitro de embriões zigóticos, isolados de sementes maduras de açaizeiro, em plântulas completas e normais.

2 - A concentração de 2,68 $\mu \mathrm{M}$ de ANA, combinada com 1,11; 1,55 ou $2,22 \mu \mathrm{M}$ de BAP, promove o melhor crescimento da parte aérea das plântulas.

3 - É necessária a presença de ANA e BAP no meio de cultura para a conversão de embriões zigóticos e para o crescimento inicial de plântulas cultivadas in vitro.

\section{REFERÊNCIAS BIBLIOGRÁFICAS}

COLLINS, G.B.; GROSSER, J.W. Culture of embryos. In: VASIL, I.K. (Ed.) Cell culture and somatic cell genetics of plants. New York: Academic Press, 1984. v.1, p.241-257.

HU, C.Y.; FERREIRA, A.G. Cultura de embriões. In: TORRES, A.C.; CALDAS, L.S.; BUSO, J.A. (Ed.) Cultura de tecidos e transformação genética de plantas. Brasília: EMBRAPA-SPI/ EMBRAPA-CNPH, 1998. v.1, p.371-393.

JARDIM, M.A.G.; OASHI, S.T.; LAMEIRA, O.N. Cartilha informativa sobre a palmeira açaí (Euterpe oleracea Mart.). Belém: MPEG, 1995.11p.

KAHN, F. The palms of eldorado. Orstom: Editions Champflour/ International Palm Society, 1997. p.40-135.

LEMOS, O.F. de. et al. Cultura de embriões zigóticos de açaizeiro (Euterpe oleracea Mart.). Belém: Embrapa Amazônia Oriental, 1999. 15p. (Boletim de Pesquisa, 23).

LLANO-AGUDELO, B.E.; GONZALEZ-ROSAS, H.; SALAZAR- 
GARCIA S. In vitro culture of mature avocado embryos. Fruits, Paris, v.50, n.1, p.59-64, jan-fév. 1995.

MURASHIGE, T.; SKOOG, F. A. revised medium for rapid growth and bioassays with tobacco tissue cultures. Physiologia Plantarum, Copenhagen, v.15, n.3, p.473-497, Mar. 1962.

O SABOR marajoara. Beira do Rio. Belém: UFPA, n.35, dez. 1992, 15 p. Edição especial.

ROBLES, M.J.M. Possibilidad de utilizar las técnicas in vitro en algunas palmeras de la amazonia peruana. In: ANEXO, 10, Lima, Peru, p.161-163, 1983.

SKOOG, F.; MILLER, C.O. Chemical regulation of growth and organ formation in plant tissues cultured in vitro. Symposia of the Society for Experimental Biology, v.11, p.118-130, 1957.

YOKOO, E.Y.; RAMOS, L.C.S.; BOVI, M.L.A. Cultura de tecidos de híbridos e espécies de palmiteiro no instituto agronômico. Campinas: IAC, 1992. 24p. (IAC. Boletim científico, 25) 